ROCZNIKI PEDAGOGICZNE

Tom 11(47), numer $4-2019$

DOI: http://dx.doi.org/10.18290/rped.2019.11.4-2

GRZEGORZ GODAWA

EWA GURBA

PAULINA RZEWUCKA

\title{
MŁODZIEŻ „POKOLENIA Z” WOBEC WDZIĘCZNOŚCI W KONTEKŚCIE WYCHOWANIA W RODZINIE
}

\author{
WSTĘP
}

Analiza wdzięczności w kontekście wychowania w rodzinie wydaje się w pełni uzasadniona. Środowisko rodzinne stwarza najwięcej możliwości do okazywania życzliwości, a także wyrażania wdzięczności za otrzymane dobro: „To, co wyróżnia ów rodzinny kontekst rozwoju psychicznego jednostki, to fakt, iż rodzina stanowi grupę społeczną, której członkowie powiązani są między sobą w sposób szczególnie intymny (w przypadku tzw. rodzin zdrowych), a owe związki mają pozytywny charakter emocjonalny" (Harwas-Napierała, 2008, s. 22). Dzięki tym związkom możliwe jest otwarcie na drugiego człowieka, obdarowanie go, a także kształtowanie umiejętności przyjmowania darów z wdzięcznością. Wychowanie do wdzięczności jest więc szczególnym zadaniem i przywilejem rodziny. Biorąc jednak pod uwagę przemiany zachodzące we współczesnym społeczeństwie i rodzinie warto postawić pytanie, czy i w jakim zakresie rodzina wciąż spełnia to zadanie.

Poszukując odpowiedzi na tak postawiony problem, poddano analizie wypowiedzi przedstawicieli Pokolenia Z, którego najmłodsi członkowie uczą się w starszych klasach szkół podstawowych, a najstarsi studiują bądź wchodzą na rynek pracy. Szczególną uwagę skupiono na młodzieży, która w roku szkolnym 2018/2019 uczyła się w klasach maturalnych. Zabrany materiał badawczy

Dr hab. Grzegorz GodAwA - Uniwersytet Papieski Jana Pawła II w Krakowie; adres do korespondencji - e-mail: grzegorz.godawa@upjp2.edu.pl; ORCID: https://orcid.org/0000-0002-2283-3965.

Dr hab. Ewa GURBA - Uniwersytet Jagielloński; adres do korespondencji - e-mail: gurbaewa@wp.pl; ORCID: https://orcid.org/0000-0003-3838-6570.

Mgr Paulina RzEwUCKA - Uniwersytet Papieski Jana Pawła II w Krakowie; adres do korespondencji - e-mail: rzewucka.paulina@gmail.com ; ORCID: https://orcid.org/0000-0002-4095-5544. 
pozwoli na ukazanie znaczenia wychowania w rodzinie dla rozwoju wdzięczności wśród młodzieży, z uwzględnieniem innych czynników wpływających na ten rozwój. Analizy pozwolą wskazać na osoby, które w wychowaniu do wdzięczności odgrywają najważniejszą rolę.

\section{POKOLENIE Z}

Pokolenie może być rozpatrywane w kilku znaczeniach, nie wykluczających się wzajemnie (Galas, 2005). Ujęcie biologiczne opisuje pokolenia jako nową generację, która przyszła na świat. Kulturowe ujęcie wskazuje na międzypokoleniowy przekaz tradycji, wiedzy i umiejętności, a podejście historyczne określa grupy ludzi o wspólnych postawach wyznaczonych przez razem przeżyte wydarzenia historyczne (Ossowska, 1963). Według K. Mannheima (1992) pokolenie tworzą członkowie społeczeństwa urodzeni w podobnym czasie, których łączą społeczne i kulturowe uwarunkowania okresu ich dzieciństwa i młodości. Do powstania trwałego związku pokoleniowego niezbędne jest indywidualne i zbiorowe uczestnictwo we wspólnym losie i ideach, związanych z rozwojem pokolenia. Związek ten charakteryzuje się tym, że jego członkowie reprezentują podobny sposób myślenia oraz postawy wobec wartości.

W klasycznym podziale pokoleń wyróżnia się:

- the Silent Generation, tworzone przez osoby urodzone w latach 1922-1944, określane jako tzw. budowniczowie współczesnej Europy;

- Baby Boomers, obejmujące osoby urodzone w latach 1945-1964, to tzw. pokolenie wyżu demograficznego i gospodarczego boomu;

- Pokolenie X, tworzone przez osoby urodzone w latach 1965-1980 i dorastające w okresie kryzysu gospodarczego;

- Pokolenie Y (tzw. millennials), urodzeni w latach 1981-1994 i wychowani w erze globalizacji i powszechnego dostępu do internetu (Hysa, 2016);

- Pokolenie Z, urodzeni w latach 1995-2010, stosunkowo często jedynacy, przyzwyczajeni do troski innych o zaspokojenie ich potrzeb;

- Pokolenie Alpha, obejmujące osoby urodzone po 2010 roku, według prognoz to najbardziej zaawansowane technologicznie pokolenie (Gruchoła, 2016).

$Z$ racji przyjętego celu artykułu nieco szerzej zostanie scharakteryzowane pokolenie Z. W literaturze odnoszącej się do tego pokolenia jest wyraźnie widoczne powiązanie tej generacji $\mathrm{z}$ nowymi technologiami informacyjnymi i wirtualnym światem. M. Wasylewicz (2016, s. 138) opisuje je w następujący 
sposób: „To pokolenie Facebooka, Instagramu, MySpace’a i SMS-ów. Mają nieustającą potrzebę bycia $\mathrm{w}$ sieci. Pokolenie $\mathrm{Z}$ to nie tylko użytkownik-konsument mediów, ale przede wszystkim twórca. To pokolenie, które zmieniło internet. Przestaje on być tylko miejscem wyszukiwania informacji, a staje się forum". Szerokie i kreatywne wykorzystanie mediów społecznościowych jest możliwe dzięki ich nieustannej dostępności, czego na co dzień doświadczają ludzie dorastający po 2000 roku. Ścisły związek z mediami spowodował, że omawiane pokolenie jest określane również jako Pokolenie $\mathrm{C}, \mathrm{w}$ nawiązaniu do angielskiego słowa connected (połączony). J. Morbitzer (2012, s. 138-139) pisze o młodych ludziach, którzy nie potrafią już żyć poza siecią: „Internet jest dla nich istotnym elementem środowiska codziennego funkcjonowania - w nim poszukują informacji, nawiązują i utrzymują przyjaźnie, słuchają muzyki, dokonują zakupów. Przedstawiciele pokolenia „C” kochają media społecznościowe, jest to zatem pokolenie nowych mediów - dzieci sieci”.

Media społecznościowe, które stają się współczesnym forum dyskusyjnym i,miejscem" spotkań, stanowią więc niezwykle istotną przestrzeń. Najczęściej wykorzystywanym przez młodzież narzędziem do połączenia z wirtualnym światem jest telefon: „Wszystko w ich życiu, zaczynając od komunikacji z członkami rodziny, szkoły, a także zarządzanie czasem, pracą i rozrywką jest realizowane z i przez telefon komórkowy. Jest on w centrum uwagi tych działań" (Gruchoła, 2016, s. 8). Warto podkreślić, iż najnowsze technologie informacyjno-komunikacyjne znacznie wykraczają poza semantyczne pole słowa „telefon”.

\section{ROLA RODZINY W WYCHOWANIU DO WDZIĘCZNOŚCI}

Pokolenie $\mathrm{Z}$ ma sposobność doświadczyć nie tylko wpływu mass mediów na kształt ich wychowania, ale także oddziaływań rodzicielskich. Rola rodziny w kształtowaniu postaw jest nie do zastąpienia, gdyż w niej dziecko uczy się norm i zasad funkcjonowania $\mathrm{z}$ innymi ludźmi oraz kształtuje system wartości i postawy względem siebie i innych ludzi (Jankowska, 2015). W tym kontekście wciąż aktualne są słowa Jana Pawła II (2005, s. 1143): „Pierwszym miejscem, gdzie rozpoczyna się proces wychowawczy młodego człowieka jest dom rodzinny”. D. Opozda (2012, s. 189), nawiązując do kontekstu pedagogicznego rodziny, podkreśla konieczność uznania jej „wyjątkowego znaczenia jako grupy naturalnej, chronologicznie pierwszej, podstawowej i niezastępowalnej w rozwoju i wychowaniu człowieka". W tym znaczeniu rodzina jest miejscem formacji 
człowieka, pracy nad sobą, kształtowania postaw oraz zbliżania się do najwyższych wartości i osiągania doskonałości (Parzyszek, 2016).

Wdzięczność należy do wartości, którym od wieków przypisywano ważną rolę w procesie rozwoju i wychowania człowieka, dlatego istotne jest jej właściwe rozumienie. Fundamentem poczucia wdzięczności jest świadomość bycia obdarowanym. Nawiązanie do zasady wzajemności jest często przyjmowane jako definiens wdzięczności. W tym ujęciu A. Smith (2006) definiuje wdzięczność jako emocję społeczną zakładającą element sympatii, sentyment, który pobudza do okazania rekompensaty za otrzymane dobro.

M.E. McCullough, R.A. Emmons i J.A. Tsang (2002) rozumieją wdzięczność jako zgeneralizowaną tendencję do rozpoznawania i odpowiadania emocją wdzięczności na życzliwość i wkład innych osób w pozytywne doświadczenia i osiągane przez kogoś rezultaty. Wdzięczność posiada szczególną właściwość wyrażającą się w tym, że podnosi u darczyńcy poczucie dobrostanu, którego wysoki poziom ma tendencję do utrzymywania się w czasie. Wdzięczność ma związek z poczuciem szczęścia, gdyż wdzięczność nasila szczęście, a szczęście sprzyja przyjmowaniu pomocy z wdzięcznością. Osoby skłonne do odczuwania i wyrażania wdzięczności bardziej cieszą się korzyściami płynącymi z życia, są bardziej świadome tego, jak cenni są dla nich inni ludzie, łatwiej dostrzegają i uświadamiają sobie, jak dobre jest życie, łatwiej przywołują pozytywne sytuacje z własnego życia, mają pozytywny stosunek do ludzi. Odnosząc się do reguły wzajemności, uruchamia to często spiralę pozytywnego sprzężenia zwrotnego w wymianie dobra i wdzięczności, co wzmacnia wzajemną więź, a tym samym sprzyja poczuciu szczęścia (Gruszecka, 2011).

Istotny wpływ na kształtowanie wdzięczności ma częstotliwość i siła doświadczanych stanów wdzięczności, co ma szczególne znaczenie w płaszczyźnie rozwojowej i wychowawczej (Tucholska, 2016). Wychowanie w rodzinie, które stanowi swoisty strumień różnorodnych wpływów skierowanych na rozwój psychiki i osobowości członków rodziny (Janke, 2007), może przyczynić się do wzmocnienia poczucia wdzięczności poprzez okazywanie wzajemnej życzliwości oraz motywowanie do okazywania jej innym: „Przy wdrażaniu do cnoty wdzięczności trzeba zwrócić uwagę na przyzwyczajanie do odpłacania i dziękowania za otrzymane dobro. Nie bez znaczenia jest również odpowiednie motywowanie" (Kluz, 2011, s. 137).

Oddziaływanie wychowawcze w kształtowaniu wdzięczności jest istotne $\mathrm{z}$ tego względu, że istnieje wiele czynników zakłócających jej rozwój. P. Kwiatek (2012) zalicza do nich: zakłócenia związane z niskim poziomem refleksyjności, 
stereotypowymi oczekiwaniami społecznymi, postrzeganiem siebie jako ofiary, poczuciem prawa i należności, osobowością narcystyczną, zaabsorbowaniem dobrami materialnymi, brakiem odpowiedniej formacji i wychowania. P. Kwiatek przywołuje wyniki badań przeprowadzonych przez E.B. Greifa oraz J.B. Gleasona, które wskazują na istotną rolę procesu wychowania w rodzinie na kształtowanie wdzięczności. Zaangażowanie rodziców w proces monitorowania i wzmacniania wdzięczności sprawiło, że $86 \%$ dzieci wykazywało zamierzony efekt, podczas gdy nie występowało owo zaangażowanie, wyraz wdzięczności u dzieci spadł do 7\% (Greif, Gleason, 1980). Pokazuje to, jak dużą rolę w kształtowaniu wdzięczności odgrywają postawy wychowawcze rodziców.

\section{BADANIA WŁASNE}

Badania przeprowadzono w grupie 200 uczniów z czterech szkół ponadgimnazjalnych w Krakowie i jego okolicach. W badaniach uczestniczyło 106 mężczyzn i 94 kobiety. Średni wiek badanych wynosił 18 lat. Badania przeprowadzono w listopadzie i grudniu $2018 \mathrm{r}$.

W badaniach wykorzystano autorski kwestionariusz „Młodzież wobec wdzięczności”. Zawierał on 28 pytań skoncentrowanych na problematyce wdzięczności, rozpatrywanej $\mathrm{w}$ różnych wymiarach i kontekstach. Przed rozpoczęciem badań zasadniczych przeprowadzono badania pilotażowe na grupie 60 osób. W niniejszej pracy wykorzystano dane pozwalające rozwiązać następujące problemy.

Pierwszy problem dotyczy spostrzeganych przez nastolatków okoliczności sprzyjających okazywaniu przez nich wdzięczności. Rozwiązanie tej kwestii pozwoli określić które $\mathrm{z}$ analizowanych czynników (wychowanie $\mathrm{w}$ rodzinie, uwarunkowania podmiotowe lub chęć zrewanżowania się) oceniane są przez młodzież jako najbardziej znaczące dla okazywania wdzięczności.

Drugi problem dotyczy pytania, kto i w jaki sposób uczył wdzięczności młodych ludzi. Wyniki wskażą postacie wybierane przez licealistów będące ich nauczycielami wdzięczności oraz metody uczenia okazywania wdzięczności.

Trzeci problem koncentruje się wokół wyboru środowisk, w których młodzież najczęściej doświadcza wdzięczności oraz wokół powiązań częstości doznawanej wdzięczności w wyróżnionych środowiskach z nasileniem postawy wdzięczności $\mathrm{u}$ badanych licealistów. Rozwiązanie tego problemu pokaże zależności między zaprezentowanymi zmiennymi. 
Czwarty problem wyraża się w pytaniu czy częstość doświadczania wdzięczności, w każdym z wskazanych środowisk, stanowi predyktor nasilenia postawy wobec wdzięczności u badanej młodzieży.

\section{WYNIKI}

Aby odpowiedzieć na pytanie, co w opinii licealistów sprzyja okazywaniu wdzięczności, obliczona została liczba badanych wskazujących na poszczególne okoliczności jako sprzyjające okazywaniu postawy wdzięczności. Wyniki przedstawiono w tabeli 1.

Tab.1. Okoliczności sprzyjające okazywaniu postawy wdzięczności

\begin{tabular}{|l|c|c|}
\hline \multicolumn{1}{|c|}{$\begin{array}{c}\text { Okazywaniu wdzięczności } \\
\text { sprzyja: }\end{array}$} & Liczba badanych & \% badanych \\
\hline Wychowanie w rodzinie & 72 & 36 \\
\hline Wewnętrzna potrzeba & 57 & 28.5 \\
\hline Własne przemyślenia & 38 & 19 \\
\hline Chęć zrewanżowania się & 29 & 14,5 \\
\hline $\begin{array}{l}\text { Korzystanie z mediów } \\
\text { społecznościowych }\end{array}$ & 1 & 0,5 \\
\hline Inne & 3 & 1,5 \\
\hline
\end{tabular}

Przedstawione wyniki pokazują, iż najwięcej badanych - 48 \% wiąże okazywanie wdzięczności z uwarunkowaniami podmiotowymi: wewnętrzną potrzebą $28.5 \%$ oraz własnymi przemyśleniami $-19.5 \%$. Na wychowanie w rodzinie, jako czynnik sprzyjający okazywaniu wdzięczności. wskazało $36 \%$ badanych, a na chęć zrewanżowania się zwróciło uwagę najmniej, bo $14.5 \%$. Wyniki wskazują na istotne - w opinii nastolatków - znaczenie wychowania w rodzinie dla umiejętności okazywania wdzięczności.

Kolejne pytanie, na które odpowiadali badani, brzmiało: „Kto i w jaki sposób uczy wdzięczności młodych ludzi?”. Aby dowiedzieć się, jakie osoby jako nauczycieli wdzięczności wskazuje badana młodzież, obliczono procenty poszczególnych wyborów. Wyniki przedstawiono w tabeli 2. 
Tab. 2. Nauczyciele wdzięczności

\begin{tabular}{|l|c|c|}
\hline \multicolumn{1}{|c|}{ Nauczyciele wdzięczności } & Liczba badanych & \% badanych \\
\hline Rodzice & 114 & 57 \\
\hline Matka & 42 & 21 \\
\hline Ojciec & 7 & 3,5 \\
\hline Dziadkowie & 10 & 5 \\
\hline Rodzeństwo & 2 & 7 \\
\hline Znajomi & 14 & 5.5 \\
\hline Inne (sam, ksiądz, Bóg) & 11 & \\
\hline
\end{tabular}

Zdaniem największej liczby badanych licealistów $-57 \%$, obydwoje rodzice są ich nauczycielami w zakresie okazywania wdzięczności. Według $21 \%$ badanych, rolę taką pełni głównie matka, a według 3.5\% wyłącznie ojciec. Na znajomych wskazało $7 \%$ badanych, na dziadków $5 \%$, a najmniej, bo tylko $1 \%$ licealistów uczyło się postawy wdzięczności od swojego rodzeństwa. Badani wskazali na rodziców jako osoby, które w codziennym życiu uczą ich okazywania wdzięczności, co jest spójne $\mathrm{z}$ wynikiem wskazującym na znaczenie wychowania w rodzinie.

Obliczono również liczbę badanych wskazujących sposoby uczenia się wdzięczności. Wyniki przedstawiono w tabeli 3.

Tab.3. Sposoby uczenia wdzięczności

\begin{tabular}{|l|c|c|}
\hline Sposoby uczenia wdzięczności & Liczba badanych & \% \\
\hline Przykład & 92 & 46 \\
\hline Tłumaczenie & 55 & 27,5 \\
\hline Przypominanie & 36 & 18 \\
\hline Nagrody & 9 & 4,5 \\
\hline Kary & 4 & 2 \\
\hline
\end{tabular}

Najwięcej licealistów - 46\% wskazało na przykład jako sposób uczenia ich postawy wdzięczności, następnie thumaczenie $-27,5 \%$, przypominanie $-18 \%$, wykorzystywanie nagród $-4,5 \%$ i kar $-2 \%$. Wyniki pokazują, iż rodzice, okazując wdzięczność innym, równocześnie uczą takiej postawy swoje dzieci.

Aby odpowiedzieć na pytanie dotyczące środowisk, w których młodzież najczęściej doświadcza wdzięczności oraz zależności między częstością dozna- 
wanej i okazywanej wdzięczności w wyróżnionych środowiskach, obliczona została liczba badanych wskazujących na środowiska, w których młodzież doświadcza wdzięczności. Porównano częstość doświadczanej wdzięczności we wskazanych przez młodzież środowiskach oraz obliczono zależności między częstością doświadczania i okazywania wdzięczności. Porównanie średnich częstości doświadczanej wdzięczności przez nastolatków w różnych środowiskach (analiza t-Studenta) pozwala stwierdzić, że $w$ ich ocenie najczęściej spotykają się $\mathrm{z}$ wdzięcznością w rodzinie i od znajomych (między umiarkowanie często a często), a istotnie rzadziej $w$ szkole i $w$ mediach społecznościowych (między rzadko a umiarkowanie często). Analiza korelacji wykazała, że istnieje istotny statystycznie związek między częstością wdzięczności doświadczanej przez badanych w poszczególnych środowiskach (rodzina, znajomi, szkoła, media społecznościowe), a częstością ujawniania przez nich postawy wdzięczności. Im częściej młody człowiek doświadcza wdzięczności w różnych środowiskach, tym częściej sam ją okazuje.

Aby odpowiedzieć na pytanie, czy częstość doświadczania wdzięczności w każdym z wskazanych środowisk stanowi predyktor nasilenia postawy młodzieży wobec wdzięczności, przeprowadzona została analiza regresji dla zmiennej wyjaśnianej - „nasilenie postawy wobec wdzięczności” i zmiennych wyjaśniających: „częstość doświadczanej wdzięczności w poszczególnych środowiskach (rodzina, znajomi, media, szkoła)". Spośród analizowanych zmiennych (częstość doświadczanej przez nastolatków wdzięczności w środowiskach: rodzinnym, szkolnym, znajomych i mediów społecznościowych) jedynie wdzięczność doznawana $\mathrm{w}$ szkole nie jest predyktorem nasilenia postawy wobec wdzięczności badanych licealistów. Częstość doświadczania wdzięczności od rodziny, podobnie jak od znajomych, wyjaśnia 5,76\% zmienności nasilenia postawy młodzieży wobec wdzięczności, a w środowisku mediów społecznościowych ta wielkość wynosi 2,89\%.

\section{WNIOSKI}

Analiza zebranego materiału badawczego wskazuje, iż badana młodzież, reprezentująca Pokolenie Z, na pierwszym miejscu odwołuje się do podmiotowych źródeł okazywania wdzięczności (wewnętrzna potrzeba i własne przemyślenia), co można wiązać z przypadającym na okres dorastania rozwojem refleksyjności, skupieniem się na własnej osobie (egocentryzm młodzieńczy) oraz 
nasilającym się dążeniem młodych ludzi do autonomii (Gurba, 2013). Interesujące jest, że znaczny procent licealistów wybrał wychowanie w rodzinie jako ważny kontekst w kształtowaniu postawy wdzięczności. Nauczycielami wdzięczności w zakresie jej okazywania są - w opinii badanych - obydwoje rodzice, a gdy wskazywany jest pojedynczy rodzic, to głównie matka. Jak twierdzą badani rodzice czynią to $\mathrm{w}$ głównej mierze poprzez własny przykład, ale wykorzystują także sugestię i perswazję. Wyniki te potwierdzają stanowisko badaczy, którzy uważają, że w przypadku przyjaznych relacji w rodzinie, rodzice w ważnych sferach życia nadal pozostają autorytetami dla nastolatków, a jedynie w takich kwestiach, jak moda czy muzyka itp. młodzież kieruje się opiniami rówieśników (Almeida, Galambos, 1993). Jak sugerują uzyskane wyniki badani adolescenci, podobnie jak eksperci w zakresie psychologii rozwoju i wychowania, wskazują na procesy modelowania i naśladowania jako główne mechanizmy nabywania nowych umiejętności czy postaw - w naszym badaniu dotyczy to postawy wdzięczności (Bandura, 1977). Tak więc rodzice, jako ważne osoby w życiu młodego człowieka, uczą postaw, zachowań, a także realizują metodykę wychowania do wdzięczności.

Wyniki potwierdzają zatem, iż wychowanie w rodzinie ma znaczenie dla rozwoju wdzięczności wśród młodzieży. Badani najczęściej spotykają się z wdzięcznością w rodzinie, ale doświadczają jej także od znajomych. Jak wynika z analiz, im częściej nastolatkowie otrzymują wdzięczność w środowisku rodzinnym, szkolnym, od znajomych i w mediach społecznościowych, tym bardziej pozytywną postawę wobec wdzięczności ujawniają. $Z$ jednej strony może to oznaczać, że postawy wdzięczności, z jakimi spotykają się młodzi w znaczących dla nich środowiskach (rodzina, znajomi), stanowią wzorce do naśladowania lub doświadczenie wdzięczności od innych motywuje do rewanżu (reguła wzajemności), a z drugiej, że okazywana przez młodych postawa wdzięczności wzbudza podobną postawę u osób $\mathrm{w}$ ich środowisku. Wyodrębnienie takich predyktorów postawy wdzięczności, jak: częstość doświadczanej wdzięczności w rodzinie, szkole i mediach, pozwala wnioskować, że okazywanie wdzięczności młodym ludziom to jedno $\mathrm{z}$ działań $\mathrm{w}$ kontekście ważnych dla nastolatków środowisk, istotne dla kształtowania u nich postawy wdzięczności.

Przeprowadzone badania pozwalają podjąć dalsze rozważania dotyczące wychowania młodzieży do wdzięczności, zwłaszcza biorąc pod uwagę kontekst rodzinny. Wyniki badań wyraźne nakreślają istotę współpracy rodziny, grupy rówieśniczej oraz szkoły w budowaniu poczucia wdzięczności oraz okazywaniu jej w życiu codziennym. Są także wskazaniem do wykorzystania mediów spo- 
łecznościowych do wzmacniania tego poczucia i budowania pozytywnych nastawień wśród użytkowników mediów. Otwiera to perspektywy dalszych badań empirycznych, pozwalających na porównanie wdzięczności w poszczególnych generacjach.

\section{BIBLIOGRAFIA}

Almeida, D.M., Galambos, N.L. (1993). Wives' Employment Hours and Spousal Participation in Family Work. Journal of Family Psychology, 7, 233-244.

BAndura, A. (1977). Social Learning Theory. Englewood Cliffs, N.J.: Prentice-Hall.

Galas, B. (2005). Pokolenie. W: T. PILCH (red.), Encyklopedia Pedagogiczna XX wieku, t. 4 (s. 513517). Warszawa: Żak.

Greif, E.B. i Gleason, J.B. (1980). Hi, Thanks, and Goodbye: More Routine Information. Language in Society, 9(2), 159-166.

GruchoŁa, M. (2016). Pokolenie Alpha - nowy wymiar tożsamości? Rozprawy Społeczne, 10(3), $5-13$.

GruSzecKA, E. (2011). Wdzięczność a szczęśliwe życie. Psychologia Społeczna, 6(19), 316-328.

GURBA E. (2013). Nieporozumienia z dorastającymi dziećmi w rodzinie. Uwarunkowania $i$ wspomaganie. Kraków: Wydawnictwo UJ.

HARWAS-NAPIERAŁA, B. (2008). Znaczenie przemian współczesnej rodziny dla rozwoju człowieka. Psychologia Rozwojowa, 3 (13), 21-27.

Hysa, B. (2016). Zarządzanie Różnorodnością Pokoleniową. Zeszyty Naukowe Politechniki Śląskiej, 97, 385-398.

JANKe, A.W. (2007). Pedagogika rodziny i wychowanie rodzinne. W: S. KAwUla, J. BrągIEL, A.W. JANKe (red.), Pedagogika rodziny. Obszary, panorama problematyki (s. 83-114). Torun: Wydawnictwo Adam Marszałek.

JANKOWSKA, M. (2015). Wychowanie jako system wzajemnych oddziaływań rodziców i dzieci. Kwartalnik Naukowy Fides et Ratio, 21(1), 5-33.

JAN PAwEe II. (1999). Homilia podczas Mszy świętej (Łowicz 14.06.1999). W: J. Poniewierski (oprac.), Jan Pawet II. Pielgrzymki do Ojczyzny 1979-2002, Przemówienia i homilie (s. 11411147). Kraków: Wydawnictwo Znak.

KLuZ, M. (2011). Rola cnót kardynalnych w wychowaniu moralnym człowieka. Studia Teologiczno-Historyczne Ślaska Opolskiego, 31, 131-145.

KwiAteK, P. (2012). Przeszkody i strategie rozwoju wdzięczności w świetle współczesnych badań psychologicznych. Seminare. Poszukiwania naukowe, 32, 151-163.

Mannheim, K. (1992). Ideologia i utopia. (tłum. J. Miziński). Lublin: Wydawnictwo „Test”.

McCullough, M.E., Emmons, R.A. i Tsang, J.A. (2002). The Grateful Disposition: A Conceptual and Empirical Topography. Journal of Personality and Social Psychology, 82(1), 112-127.

MorbitZer, J. (2012). O istocie medialności młodego pokolenia. Neodidagmata, 33/34, 131-153.

OpOzDA, D. (2012). Rodzina. VII w pedagogice. W: E. GigILEWICZ (red.), Encyklopedia Katolicka, t. 17 (kol. 188-189). Lublin: TN KUL.

Ossowska, M. (1963). Koncepcja pokolenia. Studia Socjologiczne, 2, 47-51.

PARZYSZEK, M. (2016). Rodzina miejscem pracy człowieka nad doskonałością moralną. Kultura Przemiany - Edukacja, 4, 196-206. 
SMith, A. (2006). Theory of Moral Sentiments. Săo Paulo: Metalibri.

TucholskA, S. (2016). Wdzięczność: jej natura i rodzaje. Rocznik Filozoficzny Ignatianum, 22(2), 75-99.

WASYlewiCZ, M. (2016). Transformacja sposobu komunikowania się pokolenia X, Y, Z - bilans zysków i strat. Zeszyty Naukowe Wyższej Szkoty Humanistycznej. Pedagogika, 13, 133-141.

\section{MŁODZIEŻ „POKOLENIA Z” WOBEC WDZIĘCZNOŚCI W KONTEKŚCIE WYCHOWANIA W RODZINIE}

Streszczenie

Przemiany zachodzące we współczesnym społeczeństwie i rodzinie powodują, że zmienia się znaczenie tradycyjnych środowisk wychowawczych. Kształtowanie się postaw młodych ludzi dokonuje się w coraz większym stopniu przy udziale mass mediów i grup rówieśniczych, ale rodzina wciąż stanowi potencjał dla rozwoju osobowościowego jej członków. Jest to widoczne w kształtowaniu się postaw młodzieży wobec wdzięczności, posiadającej ważne znaczenie dla funkcjonowania jednostki i społeczeństwa. Badania wypowiedzi 200 przedstawicieli Pokolenia $Z$ pokazały, że wychowanie w rodzinie wyraźnie sprzyja okazywaniu oraz rozwojowi wdzięczności, a najskuteczniejszy w tym względzie jest osobisty przykład rodziców. Współpraca środowisk wychowawczych w celu wzmacniania poczucia i okazywania wdzięczności przez młodzież jest istotnym postulatem wynikającym z przeprowadzonych badań empirycznych.

Słowa kluczowe: Pokolenie Z; młodzież; wdzięczność; rodzina; wychowanie.

\section{THE YOUTH OF GENERATION Z TOWARDS GRATITUDE \\ IN THE CONTEXT OF FAMILY UPBRINGING}

\section{S u m m a r y}

Changes in the modern society and family influence the meaning of traditional educational environments. The process of shaping young people's attitudes is increasingly affected by mass media and peer groups, but it is the family where one can still find potential for personal development. It is noticeable in the process of shaping young people's attitudes towards gratitude which is very significant for the functioning of individuals and the society. The research on 200 representatives of Generation $\mathrm{Z}$ revealed that family upbringing fosters the expression and development of gratitude. It also showed that parents setting a good example for their children are most efficient in this respect. Cooperation between educational environments in order to strengthen the sense of gratitude among young people is an important postulate resulting from the empirical research.

Key words: Generation Z; youth; gratitude; family; upbringing. 